\title{
Reinforcing Citizenship through Civil Society and Media Partnerships: the Case of Community Radios
}

Samar Samir Mezghanni, Faculty of Asian and Middle East Studies (FAMES), University of Cambridge

Keywords: Tunisia, Community Radios, Revolution, Arab Spring, Media, Civil Society

\begin{abstract}
Since 2011 the intersection between media and civil society organisations (CSOs), both of which have bloomed in Tunisia, has become a powerful source of support for the development of citizen-run (or associative), community-based radios. In identifying three critical areas in which civic media and NGOs are translating social programmes to strengthen concepts of citizenship through cooperative action - information provision, advocacy and education - this study argues that they are contributing to the development of a strong new media space in the form of citizen radios. These, often web-based broadcasters, provide opportunities, particularly for youth in both provincial and urban areas, to develop capacities as producers, consumers and story subjects, offering them new tools to experiment with blogging, citizen journalism, social messaging and identity building. The partnership of these two sectors provides significant benefits in terms of funding provision, democracy promotion and capacity building, although, it is argued, they can also place limits on the independence and future growth of these citizen radio platforms. The message, financing, and regulation of this growing field of civil society/ citizen radio output remains at the centre of a continuous negotiation of powers shifting to the public sphere.
\end{abstract}

The new political, civic and social environment that the 2011 revolution brought to Tunisia opened spaces for ideas to be expressed and circulated with less governmental censorship than previously. Media and civil society are two sectors that faced oppression and centralised control for decades. Since 2011, they have experienced significant development, which has allowed them to build partnerships and share tools particularly with popular outlets such as community radios, and practices such as citizen journalism and blogging. The exchange of these tools and ideas between media and civil society organizations is reinforced with shared capacity building programs where media corporations and CSOs merge efforts to highlight and strengthen concepts of citizenship.

Both sectors are experiencing phenomenal growth and diversification, changes they share as a result of the new environment in which they are operating. Not unexpectedly, both are seeking 
shared platforms of cooperation and are rapidly establishing opportunities for possible partnership.

\section{A new environment for free expression: Rock, paper, scissors}

The children's game 'Rock, paper, scissors' provides a useful metaphor for the intersection between media and civil society engagement vis-a-vis the government, prior to January 2011. During the Ben-Ali years, little pleasure could come with playing this game. The rules were set, and so were the results. If a journalist used paper, or by extension, a microphone or a camera, to express his or her views, it was inevitable that the content and possibly the mode of that expression would face the "censorship scissors". The same applied to those in civil society organizations. Practitioners in both sectors were constrained from expressing opposing or unconventional political views. Amin (2002) shows that the long practice of censorship on Tunisian media led to self-censorship becoming common place ${ }^{1}$. If a media outlet or a NonGovernmental Organisation (NGO) or even an individual journalist had too frequently to be censored, the risk was a "rocky" response from the Ministry of Interior. The responses could vary from seizure of the tools, to imprisonment of the "paper" player.

The creation of NGOs depended on issuing authorisation from the Ministry of Interior, which had set juridical limitations preventing the development of civil society in Tunisia. The criteria for authorising NGO creation was based on the political stance of these NGOs and whether they were complicit with the regime. The authorisation process was applied in discriminative and vague ways, giving the authorities "discretionary powers to issue or reject a visa" 2 . Reports on civil society in Tunisia show that authorised civil society was unable to address 'political' issues, and dependent on their level of adhesion to the politics and national strategies of Ben $\mathrm{Ali}^{3}$. International organisations were banned from operating in the country and sustainable funding for local ones was contingent upon their instrumentality for supporting the regime's propaganda.

The new environment created by the revolution to pursue freedom of opinion and expression is permitting both media and NGOs to operate more independently and creatively, making the results of the game appropriately unpredictable in a dynamic environment where freedom of expression is now negotiated. For NGOs, this has meant shifting control of their institutions away from the hands of the Ministry of Interior, which used to issue NGO licencing, and working under a new law published in September 2011, which protects their independence and

freedom of membership and operations ${ }^{4}$. For traditional media (TV, radio and press), the possibilities that this new environment offered permitted the expansion of ownership more robustly into the private sector after the dissolution of the Communication Ministry in 2011.

\section{The growth of media and NGOs since 2011}


Three major changes affected the civil society - media nexus in the immediate post-revolution period. First, the laws affecting them were liberalized, leading second, to a spurt in their overall numbers, and third, a resultant reconceptualisation of their role and purpose in society.

The 2007 UNICEF report on Civil Society in Tunisia showcases how those civil society organisations authorised to operate during the Ben Ali period were mainly partisan, at a time when legislative authorisation, as well as financial and administrative support, were dependent upon complicity with the regime ${ }^{5}$. This dependence was severed upon the passage in September 2011 of the 2011-88 law, regulating the environment for CSOs in Tunisia. The new law gives more freedom to NGOs, opens space for non-Tunisian ones and removed limitations on their functions.

With the privatisation of media and the independence of NGOs, the number of both has boomed since 2011. IFEDA, the Centre for information, training, studies and documentation on NGOs in Tunisia indicates the number of NGOs in Tunisia reached 17,000 in May 2014, a rise from 9,000 before the revolution ${ }^{6}$. The growth is indicative not just in the number of media outlets and NGOs, but importantly, by the enhanced sense of ownership and independence that they have gained. Reports suggest that we can speak of an advent of a new era of CSO dynamics in Tunisia $^{7}$. For media, this resulted in a diverse set of outlets ranging from new TV channels, radios including community radios, newspapers, magazines and online journalism.

With the booming of NGOs and blooming of media, more coalitions and networks have been emerging, convening practitioners and empowering their representative voices. Coalitions and networks are forming based on shared approaches to similar issues and interests such as human rights networks or entrepreneurship coalitions. NGOs are organizing into networks such as the National Network for Anti-Corruption ${ }^{8}$ and Lam Echaml ${ }^{9}$, the latter grouping over 50 organisations that share a space for information, training, tools and best practices on Human Rights, Civic Education and Citizenship. Media institutions have been organizing themselves into syndicates, such as the National Syndicate of Tunisian Journalists. Moreover, Le Syndicat des Radios Libres, a syndicate for free radios, was created representing new private and community radios and advocating for their rights. Although some of these syndicates were established before the revolution, their role in unifying practitioners and advocating for freedom of expression became more significant after it, allowing practitioners to lobby for better legislations and support to their institutions ${ }^{10}$.

\section{The new raison d'être}

The third common change in these sectors relates to the role they started to fill. In response to the liberated environment and the growth they experienced, media and CSOs have begun playing a new role within society: Before the revolution, both sectors were used as propaganda tools for Ben Ali's regime while also engaging youth in apolitical issues and topics such as sport. Media's 
"only mission was to provide the government and Ben Ali himself with a powerful and directly managed tool to disseminate messages and content which would allow a more reasonable control over the formation of public opinion" (Barata 2013, 121) ${ }^{11}$. For the majority of NGOs, this was observed in the strategies and programmes they employed to promote the regime's own strategies and vision. National youth organisations, for instance, were mainly grouped under the Tunisian Union of Youth Organisations, a union that was strongly tied to the Constitutional Democratic Rally (Ben-Ali's RCD party) carrying communication and political campaigns in schools and universities through organisations such as the Organisation of Students of the Constitutional Democratic Rally.

Following the uprising in 2011, CSOs and media started to serve three new functions: Information provision, Advocacy and Education:

Information provision: Access to information has been facilitated by the decrease in censorship. Additionally, media and civil society organisations are attempting to represent multiple views and to be less partial when transmitting information. A politicization of both sectors can be observed as they are equally affected by a heavily polarized political scene ${ }^{12}$. The expansion of media and CSO institutions (in space, functions and resources), albeit pluralistic in their domains, remain influenced by the polarized political debate in the country, as some organisations receive funding from political parties ${ }^{13}$. Al-Abdouli, an official of the Ministry of Foreign Affairs has declared that some charity organisations, supporting religious parties, have received foreign funding to support Islamist groups ${ }^{14}$. Although their creation, development and opportunities are today less conditioned by the need to spread any particular line of propaganda, civil society organizations and media have been taking political stances and projecting a "certain polarisation of visions and models that are relatively contrasted"15, referring to the agendas of secular and religious political parties. Patel and Belghith (2013) suggest that "Civil society in Tunisia is embroiled in the struggle for political power now raging in the transitional period, and civil society organisations have often appeared forced to choose between either French laïcitéinspired secularism or Ennahda-loyal Islamism" 16 .The polarisation of the sector is mainly observed through the example of organisations that officially support political parties and promote their agendas, such as the now-banned League for the Protection of the Revolution, which at times appeared to be an Ennahda affiliate. The private TV channels have also expressed strong political stances, particularly at intense times of political division, such as elections, or during moments of crisis, such as in early 2013, when opposition figures, Chokhri Belaid, and Mohamed Brahmi, were assassinated.

In spite of this, a diversity of expressed opinions and an emphasis on information rather than misinformation is developing. Research suggests that "the most popular resources of information are television programs, the internet (...) [and] youth organizations formed after the revolution that provide young Tunisians with as much information as possible about all of the newlyformed Tunisian political parties" ${ }^{\prime 17}$ (Zarlenga 2011, 12). 
Advocacy: A rising interest in advocating rights and monitoring the performance of political actors has led to the development of watchdog organisations focused on fighting corruption, and establishing accountability and transparency, such as Bawsala, and the Open Data Initiative. Media practitioners and institutions also are engaged in revealing cases of corruption and advocating for good governance. The case of Sheratongate, which erupted on 26 December 2012, and revealed by Olfa Riahi, a journalist and bogger, marked an early milestone in investigative journalism in Tunisia that advocated transparency and accountability ${ }^{18}$. The journalist posted bank and state documents on her blog that exposed the Ennahda-appointed Minister of Foreign Affairs using government funds to conduct elicit parties at the Sheraton Hotel, going on to reveal further details of the case during interviews on Ettounsia, a private TV channel. The case revealed details of financial corruption and sexual scandal, made all the more notorious as the Minister of Foreign Affairs was also a relative of Rachid Ghannouchi, Ennahdha's party leader. Although it took two years, the Sheratongate Affair brought the Minister of Foreign Affairs to court on charges of misusing public funds ${ }^{19}$ and provided a leading example of the significant counter-force that CSOs and media have become as actors in the political transition ${ }^{20}$.

Education: Before 2011, schools were used as platforms for political education and enhancing citizenship. However, the classes avoided discussing political reforms, free elections or legitimate representation. Zarlenga (2011) shows that these classes had little impact on the students and did not engage them in political issues or debates ${ }^{21}$. Since 2011 , media and civil society organisations have become key actors in developing political awareness. During the 2011 elections, both sectors made efforts to educate young people and raise awareness about political participation. Bus Citoyen, a project by six NGOs focussed on active citizenship, political education and democracy, launched a tour in all the country's governorates where volunteers met citizens in different venues (e.g. cafes, markets, schools) to sensitize them to the importance of their participation in the elections. This project inspired Barcamp, a "non-conference" based on the principles of public participation and public exchange of knowledge, which was led by a private magazine, Tunivisions, where media practitioners toured the country to discuss the young generation's vision of their future and transmitted these opinions through the magazine to the general public. Other organisations such as IWatch, gathered young people to educate them on issues of transparency and corruption while training them to monitor elections on a national and local level (e.g. elections of student representatives in universities).

\section{Merging efforts: Media and CSO partnerships}

For the purpose of this study, among the most important changes in Tunisia after the revolution has been the new tendency of CSOs and media to create partnerships and merge their efforts. This is not only caused by the intersection between the two sectors in terms of the themes and issues they deal with. In a small society such as Tunisia, it is also related to the tendency of 
activists to be media practitioners and vice versa. This particularly is the case with bloggers who are often active advocates in NGOs while being reporters and online journalists at the same time. These partnerships make the lines between media and NGOs less definable as media platforms can become a space for lobbying, advocacy and raising awareness while NGOs can become a space for disseminating information. This is illustrated in the example of al-Nawaat, established in 2004 by activist Sami Ben Gharbia, a blogger and advocate for freedom of expression and human rights ${ }^{22}$. A widely visited collective blog in Tunisia, al-Nawaat has taken it upon itself to monitor the democratic transition in the country while also focusing on "training activists on Internet technology and citizen journalism, assisting NGOs and independent activists carrying forth similar missions, monitoring elections, and continuing to publish rich and diversified content on human rights, and economic, environmental and social issues"23.

Capacity building programmes have become the most common area where media and NGOs meet and collaborate. The exchange of tools and ideas between media and civil society organizations is reinforced with shared capacity building programmes where media corporations and CSOs cooperate to reinforce citizenship. This is predominantly observable in community radios as well as NGO journalism training programmes that draw upon media expertise. Partnerships are emerging in the production of programmes highlighting active citizenship, such as "Associatif", a radio programme on Express FM. At the same time, several NGOs are developing a media component in their structured programmes that are involving journalists and media experts. The Inkyfada project, a new Tunisian web magazine, for example, brings together journalists monitoring and analysing terrorist attacks in Tunisia ${ }^{24}$. The project itself is part of $\mathrm{Al}$ Khatt NGO, an organisation that focuses on the production of journalistic content and developing good journalistic practices ${ }^{25}$.

\section{Community radios in Tunisia before and after the revolution}

Community radios refer to radios that are "grassroots or locally oriented (...), dedicated to the principles of free expression and participatory democracy, and committed to enhancing community relations and promoting community solidarity" (Howley 2005, 2) ${ }^{26}$. Manyozo (2012) proposes three approaches that can be drawn upon to analyse this phenomenon, seeing it as a characterization community development, a vector of media's role in development, and a necessary tool for participatory communication ${ }^{27}$.

The three approaches, which convene concepts of communication, development and participation, offer a conceptual framework that can explain the growth of community radio in light of technology, function and process. The development of media focuses on the use of the new technology in terms that are mutually reinforcing, in that the new freedom and independence that enables citizen-inspired media to take shape is at the same time enhanced by the capacity of the media sector. Arnold (2010) suggests that: 
"Media development starts from the assumption that the media have an important role in the state as they hold those in power accountable and provide citizens with information that they need to actively participate in the political sphere. Only an independent and free media system can achieve this. Therefore, media development targets the capacity of journalists and other media actors to fulfil their democratic function, the sustainability of independent media, and the legal environment that guarantees media freedom and independence. So it's about capacity, sustainability, and legislation. Media development takes a systemic perspective, treating media as a sector" ${ }^{\prime 28}$.

The second approach focuses on media as a process and a tool to communicate information about development projects such as health and education programmes that rely on the media to raise public awareness and change behaviours. In this approach, media is the instrument that development agendas use to inform and educate people and to attain projected development outcomes. Deane (2008) describes media for development as the media that "serves a set of social objectives which development organizations share"29.

The third approach centres on media as a process that facilitates community participation and redefines media as a participatory exercise. Manyozo advances the notion of participation as "a fundamental component of both development and communication for development, which allows for the articulation and incorporation of multiple voices and interests in the design, implementation and evaluation of development policy"30 (Manyozo 2012, 9).

In the light of these three approaches, the growth of community radio can be seen as not only a sign of the progress of media independence and freedom but as a means to solidify transitional democracy. Community radios can also be conceived of as carriers of a development discourse to raise awareness and educate the population. Furthermore, they are at the heart of community participation as they focus on community members as the producers, the recipients and the message of the radio's content. In Tunisia, community radios are a relatively new phenomenon. Few initiatives to build community radios in Tunisia were started before 2011. Just two initiatives, Radio 6 (established in 2007) ${ }^{31}$ and Kalima (founded in 2008) ${ }^{32}$ made efforts to develop their community radios and discuss themes of citizenship and human rights on the internet. The two radios were initiated by media leaders and political activists such as Salah Al Fourati and Sihem Ben Sidrine and were hosted on the web in the absence of legislative, administrative and financial support. However, they faced harassment and censorship of their web pages, which were rendered inaccessible inside the country during the ruling of Ben $\mathrm{Ali}^{33}$.

In 2005, Tunisian media activists from several NGOs (such as Club UNESCO Bardo) participated in a region-wide training programme held in Egypt and organized by the "Naseej" Foundation, a regional foundation that develops resources for community youth development in Arab countries ${ }^{34}$. The training provided a space for Tunisian participants to meet with journalists from radio "Horriyetna" and radio "Al-Balad", two popular community radios located in Egypt. The training was followed by an internship in 2007 at Horriyetna to learn from the experience of 
this radio in operating under dictatorship. However, it was only after the 2011 uprising that community radios developed in Tunisia itself as a space for citizen expression and debate on society's problems and as a platform to discuss themes of citizenship and human rights that could in particular engage the youth and enable their voices to be heard.

Community radios in Tunisia are hosted on the web and use social media to promote their programmes. They often recruit young volunteers, who are interested in journalism, to ensure low-cost production and presentation of their programmes in the absence of profitable business plans. They are usually launched as NGO projects in which they are employed to help amplify their work on freedom of expression and youth capacity building. For this reason, many citizen radios depend on funders who allocate funds to NGO programmes that tailor to their development priorities. These are usually international agencies operating bilaterally (foreign embassies and cultural centres) and multilaterally (United Nations Development Programme, European Union). Many of these organizations provide partnership and development funds to associated NGOs so they can help establish community radios in donor-targeted states. The funds are provided to support the donors' vision of open societies, local democracies and freedom of expression. In some instances, the funding achieves the intended goals, in others, the approach functions as a means of soft-power export into the target country, and as a mechanism of cultural imposition that has little bearing on the community needs or identities of the locales in which their funding is directed.

The reach of community radios in Tunisia remains minimal compared to commercial radios whose audio signal is carried by an AM or FM radio wave. Only a handful of community radios in Tunisia have reached as many as 200,000 listeners. One example is Ana Tounsi Radio, which operates online, producing programmes from its studio and facilities in downtown Tunis ${ }^{35}$. The large audience is partly explained by the capacity of the radio - located in the Bardo area where the Constitutional Assembly meets - to invite members of the parliament to discuss issues of importance with radio interviewers.

The size of community radio audiences is usually measured by online visits. The audience passes through a quick sign up procedure before beginning to listen, which enables the radio to monitor its visitors at different times of the day and the week. Most of these radios operate at specific hours in the afternoon and evening, usually from $6 \mathrm{pm}$ to $12 \mathrm{am}$ when volunteers, mostly young people, are available. The actual (often still small) audience numbers for many community radios is not in itself the critical factor, as the radios are not commercial projects; rather, it is the involvement of community members in the production of news and other programmes that is of most significance. Elyes Ezzine, the director of Ana Tounsi Radio, said "most of these volunteers are usually students, pupils, entrepreneurs and unemployed graduates." He added that "the change we see in volunteers who become engaged in issues that concern them and develop their skills throughout their career at the community radio is more important, at the moment, than the low number of audience we attract when compared to the audience commercial radios have",36. 
As an outcome of the partnerships between media and CSOs during political transition, community radio programming tends to cover themes that concern citizens, particularly those living within their areas. The radio programmes include political debates with their local Constitutional Assembly representatives, the promotion of economic and social rights, talk shows on topics related to citizenship, community, and the larger society (e.g. programmes on the lives of women in the community and its challenges), coverage of the traditions of the community through interviews with elders, and news on new projects being undertaken in the area. Other programmes involve talent shows for citizens and coverage of cultural events in the area as well as religious programmes that may broadcast Friday sermons from one of the mosques in the neighbourhood.

\section{Community radios as a powerful tool for connecting youth to their communities}

Despite being a relatively new phenomenon in Tunisia, community radios have been pushing legislative boundaries on media entrepreneurship and CSO projects, while serving pedagogical, political and societal functions within their areas of reach. Many of these radio channels were established as "associative radios", registering themselves as a project of an NGO rather than as an independent radio. The majority of these radios chose to tie themselves to NGOs and benefit from the administrative recognition and fundraising efforts they could offer. This describes, for example, Radio 3R created by the Regueb Freedom and Development organisation and Radio Ana Tounsi created by Club UNESCO Bardo. As an NGO project, community radios can raise funds from development agencies and from bilateral and multilateral donors that have set development outcomes, such as media capacity building for a target population. In the absence of a judiciary framework for community radios, these channels were able to operate as part of NGO programmes; however, at times, the connection has limited their reach and development.

After 2011, several applications for radio licensing led to an estimated 38 new radios being established on the internet by 2012, including 12 radios in youth centres ${ }^{37}$. Youth centres are governmental institutions managed by the Ministry of Youth that used to provide arenas for cultural and sport activities in many of the country's neighbourhoods. The centres were perceived as propaganda tools for Ben Ali's regime as they often hosted events promoting his leadership. Their role shifted after 2011 as they struggled to define a new identity and to generate a different reputation in order to attract young residents. Cooperation with local groups and NGOs permitted them to acquire a new role by reconnecting them to their communities and shaping them as community centres that could offer space for free debate, entrepreneurial projects and youth initiatives.

The interaction and cooperation between NGOs and community radios initiatives was enhanced

by the creation of a regional task force and fund, the Aswatona Fund for Media Development ${ }^{38}$, and monitored by other initiatives such as the Media Sustainability Index (MSI) produced by 
IREX which analyses the situation of independent media in the country ${ }^{39}$. Organisations such as World Association of Community Radio Broadcasters (WACRB) organised workshops bringing together journalists and civil society actors to plan media initiatives. These platforms facilitated collective efforts for lobbying and advocacy for the development of community media in different parts of the country, along with funders, NGOs and media institutions such as the Friedrich Ebert Foundation, and UNESCO. The World Association for Community Radio Broadcasters, for example, supported the creation of the "Voice of Mines" radio, a project of the "Voice of Others" NGO in Gafsa where the local labour movement and public demonstrations have pushed for social reform since 2008. Lobbying for better legislation concerning community radios led to the creation of a special status for "associative radios" in the statutes produced by the new media regulatory body, HAICA, in May $2014^{40}$. Twelve community radios received permission to go on air after the revolution as associative radios, five of which moved to FM radio waves - Kelma, Radio 6, Radio Karama, Radio Revolution Rgueb and Radio Chambi while the others remain web-based due to financial constraints. Moving to FM radio broadcasting is expensive and requires investment, strong managerial and staff capacities as well as sustainability plans. This has proved to be a difficult process, and is challenging community radio development, long-term sustainability and the radios' identity as non-profit initiatives. The transition can also be difficult in terms of audience acceptance. After its high-cost move to FM broadcasting in 2013, for example, Radio Kelma faced criticism, strikes and bankruptcy as it seesawed between its status as a 'revolutionary' community radio and its new position as a private radio seeking investments and advertisements to sustain its work.

\section{Challenges to community radios}

Despite the promising developments characterising the new crop of community radios, interviews with journalists and directors of community radios reveal a number of concerns and challenges that these spaces face at both the strategic and operational level. The close juridical

and financial ties between community radios and NGOs can prevent the former from firmly establishing themselves as independent media initiatives outside the ambit of their partnering NGO. Their funding is usually limited to a timeframe that depends primarily on the donors' funding commitments, which in turn depend on the donors' short term (two year) and mid-term (five year) policies, objectives and resources. These constraints keep the radio projects dependent upon, and defined by, the NGOs programmes, which can prevent them from taking the next essential step of establishing themselves as independent initiatives.

In spite of the creation of their new regulatory status, the dilemma surrounding the legal, managerial and financial status of community or 'associative' radios in Tunisia marks the relations they have with different stakeholders. The danger of other social players misperceiving or mishandling community radios is real, and constitutes the negative side of the intersection between community service organizations and small citizen media endeavours. Professional 
journalists and traditional media can be prone to discount community radios as little more than recreational activities for needy youth, or as tools for NGOs to promote their agendas. NGOs, for their part, often reduce community radios to mere 'development tools' that allow them to attain the development outcomes they must report to funders. The risk is that these misperceptions can contribute to community radios being turned into propaganda tools to be used solely for the purposes of praising the work of the partnering NGO and the youth centres in which they operate. What is more, the financial reliance of community radios presents a high risk to their sustainability not only as they remain dependent upon the budget, but likewise the priorities of international funders.

This risk is particularly present in cases where young journalists feel they are being patronised and controlled by community radios directors, which detracts from their interest and motivation to develop into radio professionals. Managers or activists within NGO programmes can likewise prove over-bearing to young journalists by imposing their own development priorities. Other decision makers in community radios such as editors, who are frequently professional or accredited journalists brought on to train volunteers, can mismanage young staff by flaunting their professional experience and qualifications. As noted by a young journalist at Ibn Khaldoun radio, "the structure and work environment are still patriarchal, with the main editor or the director of the radio making their own decisions and obliging young volunteers to abide by them, which eventually affects the motivation and enthusiasm of the youth journalists". These problems are exacerbated by the low budgets available, and the volunteer status of the radio staff, although in post-revolution Tunisia, where media contracts and employment terms remain unresolved, these are difficulties that concern not only citizen radio offices, but most media offices across the sector.

However, despite the pitfalls of the asymmetric partnership formula between NGOs and community inspired radios, and despite the difficulties faced by youth volunteers and training staffs, the majority of citizen radios have found a voice specific to their audience and their community, cementing their own longevity by serving a community that otherwise would lack the sense of political engagement, or the alternative viewpoint, that citizen radios offer.

\section{The role of community radios in Tunisia}

Besides reinforcing partnerships between the significant players (media and CSOs) throughout the political transition that started in 2011, community radios play an important role in building the capacities of marginalized youth, promoting democracy in large urban neighbourhoods and enhancing the sense of belonging and ownership of a community's residents. Among the most important new roles that community radios play are their capacity to act as pedagogical tools, as mechanisms for building democracy awareness, and as the means for developing social 
narratives and new national identities. They therefore can act as a pedagogical, democratic and social tool for building grassroots habits of citizenship.

As pedagogical tool: Community radios tend to share similar objectives to NGOs when it comes to building capacities in the target population. Previous studies have showcased this: The Declaration on Christian Education at the Second Vatican Council in 1965 stated how radio communities in Latin America, while working with community groups and organisations, supported student education by developing their cultural, political and social knowledge, helping them to become "actively involved in various community organizations, open to discourse with others and willing to do their best to promote the common good"41.

The programmes developed through NGO-media partnerships are aimed at empowering youth by involving them in the start-up, establishment and operations phases, while also including them in planning for sustainability by engaging them in discussions around fundraising and marketing. Some existing community radios, such Radio Ana Tounsi, are already equipped with training centres for young journalists and members of NGOs that are interested in building their skills in editing news, moderating debates, conducting interviews and learning press ethics. Joint training programmes are conducted by media corporations such as l'Académie Radio France International $^{42}$, while mentorship is offered by other community radios. In targeting marginalised youth in Tunisia, community radios aim to provide a space for their voices while building their media and entrepreneurial skills through practical application. Young journalists involved in these radios develop their own ethics chart and decide on the editorial line and the programmes to be included in the radio schedule. They become the leaders of this space where they can propose media projects, discuss topics that concern them the most and express themselves with enhanced communication skills. In an interview with the radio journalist Oussama Ferchichi, he confirmed that the youth volunteers he worked with have collectively decided on the editorial line of Ibn Khaldoun Radio after receiving training in journalistic ethics ${ }^{43}$.

As a democratic tool: In a transitional period where power is constantly negotiated, community radios play a major role in promoting local democracy. They permit youth to discuss the problems of the community with city council representatives after identifying the main issues through interviews with community members. Young journalists can discuss security and infrastructure challenges in their areas with local decision makers and after the interviews, continue to monitor the efforts underway through NGO accountability mechanisms. Young activists are thereby able to use interviews with decision makers to remind them - as well as the radio's audience - of their promises, and indeed, profile them at advocacy and policy-making meetings. Interviewing 145 members of the Constitutional Assembly, Ana Tounsi Radio, for example, provided space for exchanges between young journalists and political leaders where the youth could question the decisions being made and express their aspirations to their political representatives. 
By being community-led and focused, these radios encourage young journalists to create a bridge between the radio audience and the civil society organisations that want to reach them. Reporters from the radio will for example, conduct opinion polls with youth audiences to pinpoint their needs and desires, then report on common themes requested by a region's youth-to-youth centres and finally, provide youth centre directors with information to help tailor their activities to meet these needs. Saber Draouil, the director of Radio Sidi Hssine, emphasized that "these opinion polls and reports played a significant role in directing Sidi Hssine youth centre programmes to cover themes and issues that the target population requests and to organize events such as concerts and workshops around these themes"44. According to Manyozo's media development framework, this participatory and community communication process reflects

"community-based engagement approaches through which development stakeholders employ participatory communication in order to author development from below. The approach builds on participatory action research strategies from which community communication emerges to facilitate the implication of indigenous knowledge systems in deliberative development dialogue (...). The objective is to initiate 'cyclical' approach of looking, thinking (reflecting) and acting in ways that engage development stakeholders in collective planning and decision making in order to influence local development and social change ${ }^{45,}$ (Manyozo 2012, 18).

The decentralisation of the decision-making and the promotion of freedom of expression and citizenship are at the heart of any democratizing process. Some of these radios, albeit being at the inception phase, start to give power to the people of the community by enabling them to identify their concerns and discuss them with local politicians, community leaders and other decisionmakers. "In our radio talk programme called 'Zoom A'ala Sidi Hssine'”, explained Draouil, 'we discuss the problems and concerns we have about our neighbourhood with local politicians and city council officials and we challenge them to provide solutions for issues such as pollution and infrastructure in Sidi Hssine".

As social tool for citizenship, ownership and identity: In addition to their role in building capacities and promoting local democracy, community radios aim to serve a social function by connecting youth to their area and bridging the gap that often divides them from other demographic groups residing in their neighbourhoods (whether generational, gendered or socioeconomic). Most of Tunisia's urban areas are densely populated neighbourhoods where young people are marginalised. Community radios can enhance the sense of responsibility and belonging of these groups, particularly those that are the most vulnerable (youth, women and disabled community members). In his interview, Oussema Ferchichi, a journalist volunteer at Radio Ibn Khaldoun, said that "working for the radio as a reporter spread [his] social networks in the neighbourhood and allowed [him] to connect to the poorest, the most vulnerable and most marginalised residents in Ibn Khaldoun", the neighbourhood in which he interviews them and reports on their opinions ${ }^{46}$. 
In contrast to radios that focus on serving urban slums, community radios play a different role in certain provincial cities for which development agendas and funding are less prioritised and where marginalisation is felt across rural and urban areas. An example is Kerouan, a town in the middle of the country that is eclipsed by the economic and job opportunities that Sousse, its thriving coastal sister city, largely monopolizes and which, additionally, has only one privately owned radio station (Sabra FM - itself quite new) and the closest National Radio office is likewise on the coast at Monastir. The young directors/founders of the citizen station Radio Kerouan, have been very focussed, therefore, on using the radio to promote a sense of importance for the city and give it a local identity. Their efforts include highlighting social and infrastructure issues in their region, shedding light on the city's historical patrimony and developing a political consciousness "that really thinks of Kerouan", as explained by Mohamed Remmeh. "It is really important to work on our region... and to develop the life here. If we don't make change here, we won't change the region, and we won't change the nation" 47 .

An IREX study conducted soon after the revolution that involved training workshops for young, regionally based aspiring and practicing radio journalists in the provinces recommended community radios be encouraged, as there was a need to focus on rural and marginalised cities in the north and south of the country. Community radios in Gafsa, Kasserine and Regueb, where the revolution started and yet where its development fruits have so far to be reaped, are playing a crucial role in allowing young people to express themselves away from stigmatising and victimizing discourses. Radio 3R (Regueb, Revolution, Renouveau) ${ }^{48}$ in Regueb and Radio Houna Elgassrine ${ }^{49}$ in Kasserine aim to contribute to the social role valorisation of youth in these regions. Along with the purposes of education, democracy and citizenship that these radios share with others in slum zones in the capital, community radios in these rural and urban provincial areas tend to focus on the importance of their communities, emphasising the constructive role that the youth can play and providing coverage of specific economic and social problems that they face ${ }^{50}$.

\section{Conclusion}

In the past three years, the growth and development of civil society and media have been intertwined in Tunisia. The intersection between the sectors is particularly salient in the function and role they have recently started to play as media and civil society platforms and tools that can now be owned and managed by citizens who report their own stories. The audience, the producers and the reporters have moved to the public sphere were media and civil society organizations are monitoring, assessing and contributing to the political transition in the country. Communities and people, rather than a political icon such as Bourguiba or Ben Ali, now fill the headlines of newspaper stories, the TV and radio shows and the social media content. They are the stories, and their lives the message, that media corporations and civil society organizations are trying to voice. 
Community radios are playing a significant role in empowering youth as journalists, and are engaging them in the political debate at a time when youth are still struggling to overcome the image of being an "invisible generation", a phrase coined by former education minister Hatem Ben Salem. As they enhance their communication and leadership skills while developing their awareness of local issues, young people involved in community radios tend to connect to civil society organisations, and to cascade ideas and practices of active citizenship and freedom of expression in their communities. Despite often being managed by older decision-makers conditioned by the Ben-Ali years of censorship and patriarchal structures, community radios continue to create new dynamics vis-à-vis their audiences. While facing juridical concerns, financial dependence on NGOs funders and sustainability challenges, community radios likewise continue to constitute a valuable asset that can reinforce freedom of expression, youth leadership and local democracy. Their importance is further evident in areas where youth voices are marginalised and receive less attention from traditional media institutions.

When interviewing young activists, entrepreneurs and artists from 2011 to 2012 in a study tracking youth perceptions of the political, social and economic changes in Tunisia since the revolution, I came across strong condemnation of mainstream platforms as excluding youth voices $^{51}$. Young people expressed their frustration with mainstream media as being affiliated to political parties and incapable of providing transparent and neutral news, or representing and empowering those who made the revolution. At the same time, they expressed hope, as they found civil society organisations to be an alternative "third sector" that is less affected by the dichotomies faced in mainstream politics and media. The developing number of youth organizations and young volunteers in CSOs promises to engage young people to be active actors in the county's transition, rather than passive witnesses. Supporting community radio development can therefore create a space for young people to reimagine, recreate and reproduce media content that meets their expectations and represents them and their national hopes. These platforms can satisfy some of young people's ambitions of self-representation, community leadership and local democracy. As one of the interviewees put it, "There are a lot of people who want to change things. My ambition is big but the question is: do I have the means to realize it or not?" Community radio provides the promise to be one of a potential means.

As the development of radios and the role of youth are both being negotiated, community radios appear to be succeeding in promoting their communities and engaging their members in the democratic process. A key feature of the transition is the continuous negotiation to create spaces for marginalised people, particularly the youth. These contested spaces are a manifestation of a longer revolutionary process, where people are learning to gain power institutionally after having exerted it first in Tunisia's streets. 


\section{Bibliography}

Amin, Hussein. 2002. "Freedom as a Value in Arab Media: Perceptions and Attitudes Among Journalists”, Political Communication 19 (2). 125-135.

doi:10.1080/10584600252907407.

Barata, Joan. 2013. "Tunisian Media under the Authoritarian Structure of Ben Ali's Regime and After." In National Broadcasting and State Policy in Arab Countries, edited by Tourya Guaaybess, 117-130. London: Macmillan.

Bass, Thomas A. 2014. “A Woman Blogger's Scoop Helped Save Tunisia from Islamists”. The Daily Beast, June 4.

http://www.thedailybeast.com/articles/2014/04/06/a-woman-blogger-s-scoop-helped-savetunisia-from-islamists.html

Buckley, Steve, Chaabi, Sawsen and Bechir Ouarda. 2012. Etude sur le développement des médias en Tunisie: Basée sur les indicateurs de développement des médias de l'UNESCO [Study on the Development of Media in Tunisia: Based on UNESCO Indicators of Media Development]. France: United Nations Educational, Scientific and Cultural Organisation (UNESCO).

http://eeas.europa.eu/delegations/tunisia/documents/more_info/unesco_etude_surlesmedias_2012 fr.pdf

El Taraboulsi, Sherine, Samar Mezghanni, Hend Hassasi, Mohamed Yassein, and Nedal Swehli. 2013. The Revolutionary Promise: Youth Perceptions in Egypt, Libya and Tunisia. British Council and the American University in Cairo.

http://www.britishcouncil.org/sites/britishcouncil.uk2/files/revolutionary-promisesummary_0.pdf

European Union PASC Programme. 2012. Rapport de diagnostic sur la société civile tunisienne [Diagnostic Report on Tunisian Civil Society]. 
http://eeas.europa.eu/delegations/tunisia/documents/projets/rapportdiagnostic_stecivile_mars201 2_fr.pdf

Foundation for the Future. 2013. Etude sur les Organisations de la Société Civile en Tunisie [Study on Civil Society Organisations in Tunisia].

http://foundationforfuture.org/en/Portals/0/Publications/Etude\%20OSC\%20TunisieRapport\%20Final\%20v\%204.pdf

Howley, Kevin. 2005. Community Media: People, Places and Communication Technologies. Cambridge: Cambridge University Press.

Kasmi, Aljomei. 2014. “Jameiyyet khayriyya fi tounes tastathmirou almal alqatari li tamwil anshita irhabiyya" [Charity Organisations in Tunisia invest Qatari Funds to Fund Terrorist Activities]. Alarab, May 15.

http://www.alarab.co.uk/?id=22760

Kausch, Kristina. 2013. 'Foreign Funding' in Post-Revolution Tunisia. AFA, FRIDE and Hivos. http://www.fride.org/download/WP_Tunisia.pdf

Manyozo, Linje. 2012. Media, Communication and Development: Three Approaches. New Delhi: Sage.

Messaoui, Lassaad. 2007. Identification et analyse des compétences des associations actives dans le domaine de l'enfance [Identification and Analysis of the Capacities of Active Associations in the Field of Childhood]. United Nations Chidlren's Fund (UNICEF).

Metoui, Mokhtar, Mainsi, Ahmed, Gafsi, Henda and Carmen Malena. 2014. La société civile dans une Tunisie en mutation [Civil Society in a Tunisia in Mutation]. United Nations Development Programme (UNDP).

http://touensa.org/wp-content/uploads/2014/07/La-société-civile-dans-une-Tunisie-enmutation.pdf 
Ollivier, Marc. A la rencontre des medias associatifs tunisiens : Comment créer et faire vivre des médias libres? [Meeting Tunisian Community Radios: How to create and sustain free media?].

http://ismea.org/medias_tunisiens.html

Patel, Ian, and Belghith, Safa. 2013. "Leagues for the Protection of the Tunisian Revolution". Open Democracy, June 25.

https://www.opendemocracy.net/ian-patel-safa-belghith/leagues-for-protection-of-tunisianrevolution

Sallon, Helene. 2011. "En Tunisie, radio Kalima surfe sur les ondes de la libertê” [In Tunisia, Radio Kalima Surfes on the Waves of Freedom]. Le Monde, February 7.

http://www.lemonde.fr/tunisie/article/2011/02/07/en-tunisie-radio-kalima-surfe-sur-les-ondes-dela-liberte_1476067_1466522.html

Zarlenga, Erica. 2011. "Post-Revolutionary Effects: Political Self-Education of Tunisian Youth". Independent Study Project (ISP) Collection. Paper 1007.

http://digitalcollections.sit.edu/isp_collection/1007

\footnotetext{
${ }^{1}$ Amin, H. (2002), Freedom as a Value in Arab Media: Perceptions and Attitudes Among Journalists, Political Communication, 19. p125-135.

${ }^{2}$ Law $n^{\circ} 59-154$ of the 7th of November 1959, article 4, Official Journal of the Tunisian Republic $n^{\circ} 63,22$ December 1959.

${ }^{3}$ European Union Report on Civil Society in Tunisia (2012): Rapport de diagnostic sur la société civile tunisienne: http://eeas.europa.eu/delegations/tunisia/documents/projets/rapportdiagnostic_stecivile_mars2012_fr.pdf (last accessed 25th of June 2014).

${ }^{4}$ Kausch, K. (2013) 'Foreign funding' in Post-Revolution Tunisia' (AFA, FRIDE, Hivos). http://www.fride.org/publication/1128/\%E2\%80\%98foreign-funding\%E2\%80\%99-in-post-revolution-tunisia (last accessed 15th of September 2014).

${ }^{5}$ UNICEF Report on Civil Society in Tunisia (2007) : Identification et analyse des compétences des associations actives dans le domaine de l'enfance.

${ }^{6} \mathrm{http}: / / \mathrm{www}$. ifeda.org.tn/fr/presentation/ifeda/statistiques (last accessed 12th of July 2014).

${ }^{7}$ European Union Report on Civil Society in Tunisia (2012): Rapport de diagnostic sur la société civile tunisienne: http://eeas.europa.eu/delegations/tunisia/documents/projets/rapportdiagnostic stecivile_mars2012 fr.pdf (last accessed 25th of June 2014).
} 
${ }^{8} \mathrm{http://www.anticor.tn} \mathrm{(last} \mathrm{accessed} \mathrm{30th} \mathrm{of} \mathrm{August} \mathrm{2014).}$

9 http://www.lamechaml.org (last accessed 30th of August 2014).

${ }_{10}^{10}$ http://www.tunisianow.org/lوزير -الداخلية-يستقبل-وفدا-عن_النقابة_html (last accessed 28th of July 2014).

${ }^{11}$ Barata, J. (2013). "Tunisian Media under the Authoritarian Structure of Ben Ali’s Regime and After". In Guaaybess, T. National Broadcasting and State Policy in Arab Countries. London: Macmillan. p117-130.

${ }^{12}$ The political environment in post-revolution Tunisia has been contested by strongly differing political and religious stakeholders and discourse, leading to a volatile political sphere which has polarized society around competing parties and social strata, as well as contested ideologies, a situation that has informed the development of most sectors across the Tunisian landscape.

See also, European Union Report on Civil Society in Tunisia (2012): Rapport de diagnostic sur la société civile tunisienne: http://eeas.europa.eu/delegations/tunisia/documents/projets/rapportdiagnostic stecivile_mars2012 fr.pdf (last accessed 25th of June 2014).

${ }^{13}$ This in itself is not unusual for NGOs. German NGOs, for example, are closely linked to political parties (the Heinrich Böll Foundation, for example, is linked to the Alliance 90/Green Party), although funding is awarded and monitored through federal German funding bodies. See https://www.deutschland.de/en/topic/politics/germanyeurope/parties-and-political-foundations; on funding for religious charities and NGOs, see also Jeffrey J. Rodman (2008), '20 Biggest grant-making foundations for Christian Organizations', http://blogs.christianpost.com/pastor/20biggest-grant-making-foundations-for-christian-organizations-2008/ (last accessed 15th of September 2014).

${ }^{14}$ Kasmi, A. (2014). "Jameiyyet khayriyya fi tounes tastathmirou almal alqatari li tamwil anshita irhabiyya". Alarab, May 15: http://www.alarab.co.uk/?id=22760 (last accessed 30th of August 2014).

${ }^{15}$ Foundation for the Future Report on Civil Society in Tunisia (2013): Etude sur les organisations de la société civile en Tunisie: http://foundationforfuture.org/en/Portals/0/Publications/Etude\%20OSC\%20TunisieRapport\%20Final\%20v\%204.pdf. (last accessed 25th of June 2014).

${ }^{16}$ Patel, I. and Belghith, S. (2013). "Leagues for the Protection of the Tunisian Revolution". Open Democracy. June 25: https://www.opendemocracy.net/ian-patel-safa-belghith/leagues-for-protection-of-tunisian-revolution (last accessed 31st of August 2014).

${ }^{17}$ Zarlenga, E. (2011). Post-Revolutionary Effects: Political Self-Education of Tunisian Youth, Independent Study Project (ISP) Collection. Paper 1007. http://digitalcollections.sit.edu/isp_collection/1007 (last accessed 17th of June 2014).

${ }^{18}$ See http://hypotheses.org/46915 (last accessed 31st of July 2014).

${ }^{19}$ Bass, T.A. (2014). "A woman Blogger's Scoop Helped Save Tunisia from Islamists". The Daily Beast. June 4: http://www.thedailybeast.com/articles/2014/04/06/a-woman-blogger-s-scoop-helped-save-tunisia-fromislamists.html (Last accessed 11th of August 2014).

${ }^{20}$ United Nations Development Programme Report on Civil Society in Tunisia (2014): La société civile dans une Tunisie en mutation: http://touensa.org/wp-content/uploads/2014/07/La-société-civile-dans-une-Tunisie-enmutation.pdf (last accessed 25th of June 2014).

${ }^{21}$ Zarlenga, E. (2011). Post-Revolutionary Effects: Political Self-Education of Tunisian Youth, Independent Study Project (ISP) Collection. Paper 1007. http://digitalcollections.sit.edu/isp_collection/1007 (last accessed 17th of June 2014).

${ }^{22} \mathrm{http}: / /$ www.nawaat.org (last accessed 25th of July 2014).

${ }^{23}$ http://org.nawaat.org/category/media/ (last accessed $25^{\text {th }}$ of July 2014).

24 https://inkyfada.com (last accessed $15^{\text {th }}$ of August 2014).

25 http://www.alkhatt.org (last accessed $15^{\text {th }}$ of August 2014).

${ }^{26}$ Howley, K. (2005). Community Media: People, Places and Communication Technologies. Cambridge: Cambridge University Press.

${ }^{27}$ Manyozo, L. (2012). Media, Communication and Development: Three Approaches: Sage.

${ }^{28}$ Arnold, A. K. (2010). Media Development vs. Communication for Development: Structure vs. Process. http://blogs.worldbank.org/publicsphere/media-development-vs-communication-development-structure-vs-process (last accessed $11^{\text {th }}$ of August 2014).

${ }_{29}^{29}$ Deane, J. (2008). Media Development or Media for Development? Wrong question - But What's the Right One? http://www.comminit.com/policy-blogs/content/media-development-or-media-development-wrong-question-what'sright-one (last accessed $12^{\text {th }}$ of August 2014). 
${ }^{30}$ Manyozo, L. (2012). Media, Communication and Development: Three Approaches: Sage.

${ }^{31} \mathrm{http}: / /$ www.radio6tunis.net/fr/accueil (last accessed $12^{\text {th }}$ of July 2014).

${ }^{32} \mathrm{http}: / / \mathrm{www}$. kalimatunisie.com (last accessed $12^{\text {th }}$ of July 2014).

${ }_{33}$ Sallon, H. (2011) "En Tunisia, radio Kalima surfe sur les ondes de la liberté". Le Monde. February 7: http://www.lemonde.fr/tunisie/article/2011/02/07/en-tunisie-radio-kalima-surfe-sur-les-ondes-de-laliberte 1476067_1466522.html (last accessed $12^{\text {th }}$ of July 2014).

${ }^{34}$ http://www.naseej-cyd.org/en/naseej_program.php?tm=1?tm=1\&sm=2 (last accessed on 13th of July 2014). Naseej was launched in 2005 through its regional office in Amman, Jordan as a regional initiative that transitioned in early 2010 into an Independent Foundation working in and for the region. To date, Naseej programs and activities reached more than 18 countries. The Foundation works to reach its goals and thus implements its activities through providing a diverse forms of "services, opportunities and support" that are delivered through five main Programs; Financial Support, Capacity Building, Exchange and Networking, Dissemination and Production, and Advocacy. Naseej Programs are implemented.

35 http://tunein.com/radio/Radio-Ana-Tounsi-s168823/ (last accessed $8^{\text {th }}$ of July 2014).

${ }^{36}$ Interview with Elyes Ezzine, director of Ana Tounsi Radio, on the 26th of June 2014.

${ }^{37}$ UNESCO Study on Media in Tunisia (2012) : Etude sur le développement des médias en Tunisie: http://eeas.europa.eu/delegations/tunisia/documents/more_info/unesco_etude_surlesmedias_2012_fr.pdf

${ }^{38}$ http://aswatona.net/?page id=16307 (last accessed $12^{\text {th }}$ of July 2014). The Aswatona Fund for Media Development is a partnership project of Community Media Solutions (UK), Community Media Network (Jordan), Andalus Institute for Tolerance and Anti-Violence Studies (Egypt), Holy Land Trust (Palestine), Forum Alternatives du Maroc and the Syndicat Tunisien des Radios Libres, in association with World Association of Community Radio Broadcasters (AMARC). It is part of the EU-funded 'Media and culture for development' programme.

${ }^{39} \mathrm{http} / / / \mathrm{www}$.irex.org/resource/tunisia-media-sustainability-index-msi (last accessed $8^{\text {th }}$ of August 2014).

${ }^{40} \mathrm{http} / / /$ haica.tn/media/cahier-des-charges-radio-associative.pdf (last accessed $8^{\text {th }}$ of July 2014).

${ }^{41}$ Second Vatican Council, 1965a, Section 1.

${ }^{42} \mathrm{http}: / /$ academie.france24-med-rfi.com/fr (last accessed 10th of August 2014).

${ }^{43}$ Interview with Oussama Ferchichi, journalist at Ibn Khaldoun Community Radio, on the 23rd of June 2014.

${ }^{44}$ Interview with Saber Darouil, director of Sidi Hssine Community Radio, on the 25th of June 2014.

${ }^{45}$ Manyozo, L. (2012). Media, Communication and Development: Three Approaches: Sage.

${ }^{46}$ Interview with Oussama Ferchichi, journalist at Ibn Khaldoun Community Radio, on the 23rd of June 2014.

${ }^{47}$ Personal interview with Mohamed Remmeh and Fawzi Monastiri conducted by interviewers with the University of Cambridge-al-Jazeera Centre for Studies Media Project.

${ }^{48} \mathrm{http} / / / \mathrm{www}$. radio3r.org/ar/ (last accessed 31st of August 2014).

${ }^{49} \mathrm{http}: / / \mathrm{www}$.radio-kasserine.tn (last accessed 30th of August 2014).

${ }^{50}$ http://ismea.org/medias tunisiens.html (last accessed 30th of August 2014).

${ }^{51}$ El Taraboulsi, S. Mezghanni, S. Hassasi, H. Yassein, M. and Swehli, N. (2013). The Revolutionary Promise: Youth Perceptions in Egypt, Libya and Tunisia: http://www.britishcouncil.org/sites/britishcouncil.uk2/files/revolutionary-promise-summary_0.pdf (last accessed 31st of August 2014). 